\title{
An Endless Struggle of Fighting Discrimination in the Name of Human Rights Protection
}

\author{
Hernadi Affandi ${ }^{*}$, Tarsisius Murwadji* \\ DOI: https://doi.org/10.22304/pjih.v7n2.a4
}

Submitted: June 23, 2020 | Accepted: August 12, 2020

\begin{abstract}
The Incident of George Floyd's death reminds people of the peril of discrimination that still exists within the American society. The incident has triggered worldwide reactions from people who feel sympathy for the victim and reject racism. To eliminate racial discrimination, every modern society needs to remove any negative paradigm towards intergroup relation. In the context of the United States, the American Government has the responsibility to protect the rights of citizens from any forms of discrimination. That includes racial discrimination. In addition, people have to be reminiscent of the danger of racial discrimination in the modern era. The danger has the ability to disturb human rights protection. This study revealed history, criteria, and impacts of discrimination within the scope of human rights protection.
\end{abstract}

Keywords: African-Americans, human rights, racial discrimination.

\section{Memerangi Diskriminasi dalam Perlindungan Hak Asasi Manusia: Perjuangan Tiada Akhir}

\begin{abstract}
Abstrak
Insiden George Floyd seakan mengingatkan kembali bahaya diskriminasi yang masih ada di masyarakat AS. Kejadian itu memunculkan reaksi dari orang-orang yang turut bersimpati dan menolak rasialisme dari seluruh belahan dunia. Masyarakat modern semestinya sudah mengubah pandangannya yang negatif terhadap kelompok lain, sehingga tidak terjadi diskriminasi rasial. Oleh karena itu, pemerintah AS memiliki tanggung jawab untuk melindungi hak warga negaranya dari segala bentuk diskriminasi termasuk diskriminasi rasial. Di samping itu, masyarakat perlu diingatkan kembali tentang bahaya diskriminasi rasial di era modern yang dapat mengganggu perlindungan hak asasi manusia. Tulisan ini akan menyoroti tentang sejarah, tolak-ukur, dan akibat diskriminasi terhadap perlindungan hak asasi manusia.
\end{abstract}

\section{PADJADJARAN Journal of Law Vol. 7 Number 2 Year 2020 [ISSN 2460-1543] [ISSN 2442-9325]}

Lecturer of Constitutional Law Department, Faculty of Law Universitas Padjadjaran, Jl. Dipati Ukur No. 35, Bandung, S.H. (Universitas Padjadjaran), LL.M. (Universiteit Utrecht the Netherland), Dr. (Universitas Padjadjaran), hernadi.affandi@unpad.ac.id

** Professor of Economic Law Department, Faculty of Law Universitas Padjadjaran, Jl. Dipati Ukur No. 35, Bandung, S.H. (Universitas Padjadjaran), M.H. (Universitas Indonesia), Dr. (Universitas Gadjah Mada), t.murwadji@unpad.ac.id 
Kata kunci: Afro-Amerika, diskriminasi rasial, hak asasi manusia.

\section{A. Introduction}

The arrest of an African American George Floyd by some Caucasian-ethnic police officers caused the loss of his life. The event is surely a reminder of the danger of discrimination. ${ }^{1}$ Discrimination is not only about the possibility of life cost, but it also implies a prejudiced act from one group of people against another. The event may happen differently if the victim was of other group than African American or the culprit was not Caucasians. The event shows that the problem of discrimination within the American society is like ticking time bomb that ready to explode at any moment and grow following trigger factors. The George Floyd case has triggered the anger of African Americans against the Caucasians. The anger has also ignited emotions of white US citizens, who are anti-racial discrimination, even the world community who sympathizes with Floyd.

The George Floyd incident is not the only example of racial discrimination in the United States. There have been similar cases within the last five years, for instances the cases of Eric Garner, Michael Brown, and Tamir Rice in 2014; Walter Scott in 2015; Altor Sterling and Philando Castile in 2016; and Breonna Taylor in 2018. ${ }^{2}$ These are cases appeared and published. There could be other cases unrevealed to the public. In other words, it is like the tip of the iceberg. These are examples that discrimination occurs in the modern US.

The Floyd incident has triggered protests that were followed by riots throughout the US. The people of the US are not the only party who feel the impact. If affects All states of the world. In other words, discrimination is not merely a domestic problem, but it has been an international issue. The world shows sympathy to the victims of the cases. It is a deeply regret that discrimination still exists in the most modern state of the world, the US. Racial sentiment would not occur if the victims were not African American descents. In general, the feeling is disturbed when such cases are related to racial discrimination. Therefore, the incidents show us that discrimination always arises when a group of people feel themselves superior compared to others. ${ }^{3}$

The incident has opened the eyes of the world that discrimination still exists and can always be exist in the US. The US is a champion of human rights protection and enforcement, but they still have problems of racial discrimination. Nevertheless, the US cannot waive from the experience of racial discrimination. This fact brings out anomaly in the human rights protection and enforcement. In this context, state should protect all citizens automatically without any distinction.

BBC News, "George Floyd: What Happened in the Final Moments of His Life", https://www.bbc.com/news/world-us-canada-52861726, accessed on June 7, 2020.

2 BBC News, "George Floyd: Timeline of Black Deaths Caused by Police", https://www.bbc.com/news/world-uscanada-52905408, accessed on June 7, 2020.

3 Lawrence M. Friedman and Grant M. Hayden, American Law an Introduction, 3rd edition, New York: Oxford University Press, 2017, p. 27. 
There should not be a superior group within an equal society, for instance, whites' superiority over blacks.

Diangelo describes white supremacy a realm that covers political, economic, and social system. It does not only refer to certain group of people and their intentions or actions. ${ }^{4}$ Furthermore, many scholars use the term to describe a sociopolitical-economic system of domination based on racial categories that benefits a group of people perceived as white. In other words, the system centralizes and elevates whites as a group with certain benefits. ${ }^{5}$ Historically, white supremacy originated in the West. It circulates globally and the concept has existed for about four hundred years. ${ }^{6}$

Various racial discrimination incidents in the US raise questions and discourses on the motives in the current modern era. The US seems still trapped in the past. They have not been able to eliminate the negative stigma coming from history of disrespecting varieties of race, color, sex, religion, language, etc. the US society still bears a stigma as a racist society and have not appreciated and upheld the differences. King states plainly, "The vast majority of white Americans are racists, either consciously or unconsciously." Therefore, some may say that racism is so American so that, when people protest racism, some will assume they are protesting America. ${ }^{8}$

Incidents of racism may happen in any heterogeneous societies. Therefore, it seems that people still need to comprehend the meaning of discrimination, especially racial discrimination. Racism and sexism affect conscious prejudice, discrimination, or antagonism directed against someone of a different race or sexbased on the belief that one's race or sex is superior. ${ }^{9}$ This basic lesson seems to be forgotten because it only touches the surface without being implemented due to various reasons. It is an irony that a modern society has already known human rights but still practices racial discrimination.

The most important things to be comprehended are the meaning and the criteria of discrimination. A better understanding can equip people with a comprehension that discrimination is unacceptable so that it must be avoided. Avoiding the criteria surely will lead people to human rights violation. Indeed, human rights violation covers not only discrimination. However, discrimination is clearly a human rights violation. Discrimination is a dangerous threat to protection

\footnotetext{
Robin Diangelo, White Fragility Why It's So Hard for White People to Talk Racism, Boston: Beacon Press, 2018, p. 24.

6 Crystal M. Fleming, How to Be Less Stupid About Race on Racism, White Supremacy, and the Racial Divide, Boston: Beacon Press, 2018, p. 30.

7 Eddie S. Glaude Jr, Democracy in Black How Race Still Enslave The American Soul, New York: Crown Publisher, 2016, p. 72.

8 Eddie S. Glaude Jr, op.cit., p. ii.

9 Matthew Horace and Ron Harris, The Black and The Blue a Cop Reveals the Crimes, Racism, and Injustice, in America's Law Enforcement, New York: Hachette Book Group, 2018, p. 1.
} 
and enforcement of human rights because it is one of most common forms of human rights violations. Officials and people in many states still practice discrimination. Instead of protecting and fulfilling human rights, state apparatus sometimes performs human rights violations. People also practice the same thing due to various reasons.

This article discusses history, criteria, and comprehension of discrimination. These aspects need to get attention to prevent the occurrence of various forms of discrimination within modern society.

\section{B. Discrimination as Classical Problems Annoying Human Civilization}

Human history is inseparable from the practices of discrimination. Majority group usually carries out the practices due to the feeling of superiority. ${ }^{10}$ Some people seem to have unchanged views. As a result, discrimination can be considered a classic problem, a legacy of the past surviving in modern human civilization. The events in the US appear to bring back the past where human rights violations often occurred in the form of racial discrimination against African American. The problem always haunts the lives of African Americans because the Caucasians treats them less humanely.

Historically, the US has a long history of slavery legalized by the authorities. Formally, it was confirmed by the Constitution. Therefore, slavery was considered a legal action supported by the state and people. Article I Section II paragraph 3 defined slave as three-fifths a man. The term slave here meant any person of African descent, either free or not. ${ }^{11}$

According to Lehman, European and American historians generally dealt with the subject of African American bond-labor on the basis of an unchallenged assumption of a natural instinct of 'racial' domination. ${ }^{12}$ However, after the shift of consciousness following the World War II and the Civil Rights movement, the consensus of social sciences was "that the historical roots of racism were traceable to the slave system". ${ }^{13}$ Therefore, it is a never ending debate on the correlation between slavery and racism. ${ }^{14}$

Theoretically, racism is divided into traditional and modern. Traditional racism is identified as beliefs about African American being inherently inferior to Caucasian. ${ }^{15}$ On the other hand, modern racism features a resistance to change social structure that favors some races over others. It is a belief that racism

\footnotetext{
10 Hernadi Affandi, Persamaan Kedudukan di Depan Hukum dan Pemerintahan Konsepsi dan Implementasi, Bandung: CV Mujahid Press, 2017, p. 309.

11 Paul R. Lehman, America's Race Problems a Practical Guide to Understanding Race in America, Maryland: University Press of America, 2009, p. 12.

Ibid.

Ibid.

14 Kenneth N. Addison, "We Hold These Truths to Be Self-Evident ..." Interdisciplinary Analysis of the Roots of Racism and Slavery in America, Maryland: University Press of America, 2009, p. 167.

15 Jaemi L. Flexon, Racial Disparities in Capital Sentencing Prejudice and Discrimination in the Jury, El Paso: LFB Scholarly Publishing LLC, 2012, p. 37.
} 
concerns to the past; and that minority are being given too much attention in policy of resources allocation. ${ }^{16}$ According to Banton, racial discrimination is based on an erroneous nineteenth-century doctrine that every human belonged in some racial category, which influence upon abilities and social position. ${ }^{17}$

Eventually, the differences lead to the civil war between the North and the South. However, the end of the civil war also did not end slavery necessarily, despite the fact that it was abolished formally. On the sociological level, racial discrimination continues clearly in the form of social segregation. In other words, racial discrimination is hard to be eliminated from the American people because, constitutionally, Congress does not have the authority to stop racial discrimination.

The principle of equality in the United States emerged after the civil war ended. The principle was incorporated formally into the Constitution through the fourteenth amendment. The principle is known as the Equal Protection Clause. According to Glaude, neither the Thirteenth nor the Fourteenth Amendments gave the Congress power to restrict racial discrimination in the private sector. In line with Glaude, Chemerinsky explains as follows.

"After the Civil War, widespread discrimination against former slaves led to the passage of the Fourteenth Amendment, which provides in part "No state shall ... deny to any person within its jurisdiction the equal protection of the laws". 18

Bradley clarifies that in the view of the court, the Fourteenth Amendment prohibits discriminatory "state action" against African American. However, it does not prohibit by one individual against another in the private sector. This judgment made the federal government unable to involve in the eradication of discrimination in private sector. ${ }^{19}$ The end of slavery was followed by the Jim Crow era enabling legal separation. In Southern states, the African Americans were legally excluded from accesses to schools, hospitals, restaurants, and rest areas used by the Caucasians. $^{20}$

According to Smith, segregation is a system that argues for absolute, intrinsic, static, and meaningful difference between blacks and whites. It is a product of a late-nineteenth-century, in which southern segregationists found they could no longer rely solely on their modern eyes to verify all sorts of truths, racial ones included. ${ }^{21}$ On the other hand, Glaude mentions that the idea of "Black America" is

\footnotetext{
Ibid.

Michael Banton, International Action Against Racial Dicrimination, Boston: Clarendon Press, 2003, p. 52.

Erwin Chemerinsky, Constitutional Law Principles and Policies, New York: Aspen Publishers, 2002, p. 642.

Cal Jillson, American Government Constitutional Democracy Under Pressure, New York: Routledge, 2018, p.

110.

20 Thomas E. Patterson, The American Democracy, $2^{\text {nd }}$ edition, New York: McGraw-Hill, 1993, p. 7.

21 Mark S. Smith, How is Race Made, Slavery, Segregation, and the Senses, Chapel Hill: The University of South Carolina Press, 2006, p. 7.
} 
a bit tricky. It has two possible meanings: (1) the collective group of Black Americans exists today; and (2) the set of institutions that have traditionally served as the foundations of black communities in America since the early nineteenth century. $^{22}$

Discriminatory treatment in the past was not only performed by the State but was also supported by the community. The Ku Klux Klan is an example of a racist group of White Americans supporting discrimination by intimidating blacks and their white allies. ${ }^{23}$

Simmons explains that the Ku Klux Klan stands for: ${ }^{24}$

1. one hundred percent Americanism and re-consecration to bedrock principles;

2. white supremacy; and

3. to protect woman's honor and the sanctity of home.

This situation continued until the 1960s when it was formally ended by the birth of the Civil Rights Act in 1964. The bill was proposed by President John F. Kennedy in 1963 and it continued by his successor President Lyndon B. Johnson. ${ }^{25}$ However, this Act again did not end anti-black sentiment. Nevertheless, there was a change in the view of people towards blacks, while some still underestimated the blacks. The fight against racial discrimination occurs not only in the United States, but also in Europe, Asia, Australia, and Africa. The story of international action against racial discrimination, as against many other evils, covers the struggle to extend the rule of law. ${ }^{26}$ Only in 1965, discrimination against Chinese, Japanese, and other Asians was eliminated from the immigration laws. ${ }^{27}$ Racial discrimination includes not only social and economic but also politics.

Constitutionally, the requirements to become a President of the United States are very simple. They are stated in Article II, Section I, paragraph 5 that reads "No person except a natural born Citizen, or a Citizen of the United States, at the time of the Adoption of this Constitution, shall be eligible to the Office of President; neither shall any Person be eligible to that Office who shall not have attained to the Age of thirty-five Years, and been fourteen Years a Resident within the United States ". In practice, these requirements were not easy to be implemented because of public expectation factors. Although the Constitution does not mention gender and race requirements, these two are barriers that limit a person to be a president. ${ }^{28}$ In the

Eddie S. Glaude Jr, op.cit., p. 89.

23 Norman K. Risjord, America, A History of the United States, Volume 1 to 1877, New Jersey: Prentice-Hall, Inc., 1985, p. 474.

24 Sarah Churchwell, Behold America A History of America First and the American Dream, 1st edition, London: Bloomsbury Publishing, 2018, p. 93.

Paul R. Lehman, op.cit., p. 38.

Michael Banton, op.cit., p. 1.

Thomas E. Patterson, We the People an Introduction to American Government, $11^{\text {th }}$ edition, New York: McGraw-Hill Education, 2013, p. 13.

28 Robert Weissberg, Understanding American Government, New York: Random House School Division, $1988, \mathrm{p}$. 312. 
history of the United States, there had been presidential candidates who are female, like Margareth Chase Smith in 1964; and who are of African Americans, like Jesse Jackson in 1984. Unfortunately, there are only white men who are seriously considered. ${ }^{29}$

The Presidential Election was very influenced by the views of the people towards their candidates. In addition, public expectation is also related to issues of morality and lifestyle. ${ }^{30}$ In this case, for example, Americans want a married President, with a family, running a traditional religion, or not divorced. ${ }^{31}$ Thus, such unofficial requirements can be barriers for someone to run for presidential and vice-presidential candidates.

Under these circumstances, it is not surprising that Patterson states as follows. ${ }^{32}$

"... some Americans are still struggling for equal rights. In theory, Americans are equal in their rights, but in reality, they are not equal, nor have they been. African-Americans, women, Hispanic-Americans, the disabled, Jews, American Indians, Catholics, Asian-Americans, homosexuals, and members of nearly every other minority group have been victims of discrimination in fact and in law."

The note indicates that racial discrimination still exists in modern American society. Similar situations may exist in other parts of the world, especially in relatively developing countries. This proves that discrimination always lives because of one group's superiority.

\section{Criteria of Discrimination in Doctrine and International Human Rights Instruments}

Lexically, discrimination means treating a person less favorably on grounds unrelated to merit, usually because the person belongs to a particular group or category. Either direct or indirect, it includes victimization and harassment. In fact, it is unlawful to discriminate on grounds of race, sex, sexual orientation, religious affiliation, belief, and disability. ${ }^{33}$ Since December 2006, age has been added to the list of prohibited grounds. Therefore, the criteria of discrimination, according to the dictionary, comprises of race, sex, sexual orientation, religion or belief, disability, and age.

Black's Law Dictionary mentions that discrimination are (1) the effect of a law or established practice that confers privileges on a certain class or that denies

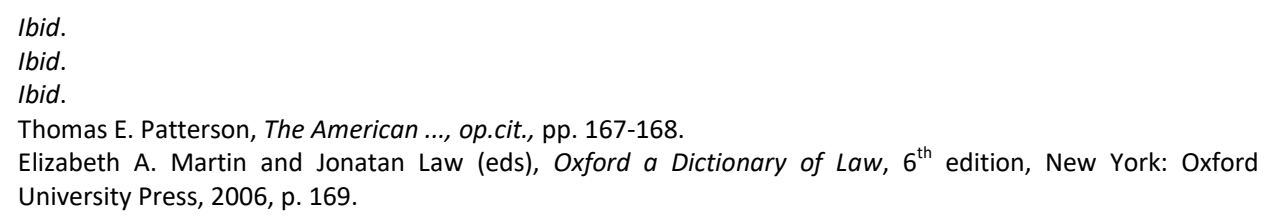


privileges to a certain class because of race, age, sex, nationality, religion, or disability; and (2) differential treatment -especially a failure to treat all persons equally when no reasonable distinction can be found between those favored and those not favored. ${ }^{34}$ Based on the definition, the discrimination criteria include race, age, sex, nationality, religion, or disability.

In general, the criteria of discrimination, based on the two dictionaries, equally cover race, sex, religion or belief, disability, and age. Both of them also place race at the first order, while the rests are in different orders. There are also different examples made by the two dictionaries, namely sexual orientation (the Oxford Dictionary) and nationality (the Black's Law Dictionary).

According to Nowak, discrimination is distinctions on the grounds of race, color, language, birth, religion, gender, national, or social origin. Nowak adds, "More recently, other distinction criteria such as sexual orientation, age, disability, and belonging to national minorities were also declared highly condemnable". ${ }^{35}$ On the other hand, Hemond states, "discrimination occurs when people are treated differently because of their sex, sexual orientation, or membership in an ethnic, linguistic, national, rational or religious group". ${ }^{36}$

Based on the ideas of both Nowak and Hemond, discrimination criteria cover race, color, language, birth, religion (religious group), gender, national (minorities), social origin, sex, sexual orientation, age, disability, ethnicity, and rational. All together, the two opinions differ in determining discrimination criteria. The similarities are sexual orientation, linguistics, national (minorities), and religion (religious group).

Normative understanding and criteria of discrimination have been regulated in various international instruments since the mid-twentieth century. Following the World War II, international organizations have acknowledged the principle of nondiscrimination. ${ }^{37}$ The instruments are called declarations, covenants, conventions, protocols, etc. International human rights instruments generally prohibit racism or racial discrimination. ${ }^{38}$

Eidi explains the International Bill of Human Rights consisting of the Universal Declaration of Human Rights, the International Covenant on Civil and Political Rights, and the International Covenant on Economic, Social, and Cultural Rights. ${ }^{39}$

34 Bryan A. Garner, (ed), Black's Law Dictionary, $9^{\text {th }}$ edition, New York: West a Thomson Reuters Business, 2009, p. 534.

35 Manfred Nowak, Introduction to the International Human Rights Regime, Leiden: Martinus Nijhoff Publishers, 2003, p. 61.

36 Elaine Hemond, "Women's Political Equality the Project of The Century", Groupe Femmes et Democratie Papers, Vol. 7, No. 2, December 2007, p. 3.

37 Erna Appelt and Monika Jarosch (eds), Combating Racial Discrimination Affirmative Action as a Model for Europe, New York: Berg, 2000, p. 3. Ibid.

39 Asbjorn Eidi, "Economic, Social, and Cultural Rights as Human Rights" in Asbjorn Eidi, (et.all), Economic, Social, and Cultural Rights a Text Book, $2^{\text {nd }}$ revised edition, Dodrecht: Kluwer Law International dan Martinus Nijhoff Publisher, 2011, p. 9. 
Other instruments of human rights and the prohibition of discrimination that are also important are the Charter of United Nations and the Universal Declaration on the Elimination of All Forms of Racial Discrimination.

The following discusses the international instruments. The discussion follows the orders of each instrument. At least five instruments are elaborated. They are the Charter of the United Nations (United Nations Charter), the Universal Declaration of Human Rights (UDHR), the International Covenant on Civil and Political Rights (ICCPR), the International Covenant on Economic, Social and Cultural Rights (ICESCR), and the International Convention on the Elimination of All Forms of Racial Discrimination (CERD).

\section{The Charter of the United Nations}

The United Nations Charter is established on June 26, 1945, in Chinese, French, Russian, English, and Spanish languages. On the objectives of the establishment of the UN, Article 1 paragraph 3, stipulates, "To achieve international cooperation in solving international problems of an economic, social, cultural, or humanitarian character, and in promoting and encouraging respect for human rights and for fundamental freedoms for all without distinction as to race, sex, language, or religion". This article does not mention the word 'discrimination' and, instead it mentions the word 'distinction' with the same meaning.

This is reaffirmed in other articles, such as Articles 13, 55, and 76. Article 13 paragraph 1 (b) states the intention of "promoting international cooperation in the economic, social, cultural, educational, and health fields, and assisting in the realization of human rights and fundamental freedoms for all without distinction as to race, sex, language, or religion". Thus, the UN Charter mentions four criteria of distinction: race, sex, language, and religion.

What is more, Article 55 (c) reads "universal respect for, and observance of, human rights and fundamental freedoms for all without distinction as to race, sex, language, or religion". Article 76 (c) states "to encourage respect for human rights and fundamental freedoms for all without distinction as to race, sex, language, or religion, and to encourage recognition of the interdependence of the peoples of the world". Both articles also mention discrimination criteria, namely race, sex, language, or religion.

\section{Universal Declaration of Human Rights}

The UDHR was issued on December 10, 1948. It is considered to be the first major international instrument to assert individual rights and freedoms. ${ }^{40}$ The declaration contains 30 articles covering individual integrity, political rights, and civil rights

40 United Nation, Inter-Parliamentary Union, The Convention on the Elimination of All Forms of Discrimination against Women and its Protocol, Handbook for Parliamentarians, Secretary of the Publication Boards, New York: United Nations Headquarters, 2003, p. 7. 
(such as freedom of thought, expression, religion, assembly, and access to the political process). ${ }^{41}$ In addition, the declaration also contains economic rights (such as the right to work, education, social security, and full involvement in society). ${ }^{42}$

The affirmation that humans are born equal is affirmed in Article 1 as follows.

"All human beings are born and equal in dignity and rights. They are endowed with reason and conscience and should act towards one another in a spirit of brotherhood." Furthermore, Article 2 emphasized that "Everyone is entitled to all the rights and freedoms set forth in this Declaration, without distinction of any kind, such as race, color, sex, language, religion, political or other opinion, national or social origin, property, birth or other status."

On human rights and freedoms, there are Articles 3, 6, and 7. Article 3 states as follows.

"Everyone has the right to life, liberty and the security of person."

Article 6 reads as follows.

"Everyone has the right to recognition everywhere as a person before the law."

Article 7 emphasizes the following.

"All are equal before the law and are entitled without any discrimination to equal protection of the law. All are entitled to equal protection against any discrimination in violation of this Declaration and any incitement to such discrimination."

Article 16 paragraph 1 reads as follows.

"Men and women of full age, without any limitation due to race, nationality or religion, have the right to marry and to found a family. They are entitled to equal rights as to marriage, during the marriage, and at its dissolution."

Article 23 paragraph 1 reads as follows.

"Everyone, without any discrimination, has the right to equal pay for equal work."

Article 16 uses the word limitation. Article 23 uses the word discrimination. It appears that the UDHR regulates the criteria of distinction, discrimination, or limitation in the same sense. Based on the UDHR, the criteria of distinction, discrimination, or limitation consist of thirteen. They are race, color, sex, language, religion, political or other opinions, national or social origin, property, birth, or another status. 


\section{International Convention on the Elimination of All Forms of Racial Discrimination}

The CERD is adopted and opened for signature and ratification based on the General Assembly resolution 2106 (XX) in December 21, 1965. It is valid since January 4, 1969. The CERD intends to eliminate all forms of discrimination. It contains definitions, criteria, forms of discrimination, etc.

In the Preamble of the Convention, there are several considerations as reason issuance of the Convention.

"- Considering that all human beings are equal before the law and are entitled to equal protection of the law against any discrimination and against any incitement to discrimination,

- Convinced that any doctrine of superiority based on racial differentiation is scientifically false, morally condemnable, socially unjust and dangerous, and that there is no justification for racial discrimination, in theory or in practice, anywhere,

- Reaffirming that discrimination between human beings on the grounds of race, colour or ethnic origin is an obstacle to friendly and peaceful relations among nations and is capable of disturbing peace and security among peoples and the harmony of persons living side by side even within one and the same State,

- Convinced that the existence of racial barriers is repugnant to the ideals of any human society,

- Alarmed by manifestations of racial discrimination still in evidence in some areas of the world and by governmental policies based on racial superiority or hatred, such as policies of apartheid, segregation or separation."

The definition of racial discrimination is affirmed in Article 1 paragraph 1 as follows.

"In this Convention, the term "racial discrimination" shall mean any distinction, exclusion, restriction or preference based on race, color, descent, or national or ethnic origin which has the purpose or effect of nullifying or impairing the recognition, enjoyment or exercise, on an equal footing, of human rights and fundamental freedoms in the political, economic, social, cultural or any other fields of public life."

Thus, the fundamentals of racial discrimination are race, color, descent, or national or ethnic origin.

Article 2 paragraph 1 emphasizes the following.

"States Parties condemn racial discrimination and undertake to pursue by all appropriate means and without delay a policy of eliminating 
racial discrimination in all its forms and promoting understanding among all races, ..."

Article 4:

"propaganda and all organizations which are based on ideas or theories of superiority of one race or group of persons of one color or ethnic origin, or which attempt to justify or promote racial hatred and discrimination in any form, ..."

Moreover, specifically, the content material confirms the prohibition of discrimination in Article 5 as follows.

"In compliance with the fundamental obligations laid down in article 2 of this Convention, States Parties undertake to prohibit and to eliminate racial discrimination in all its forms and to guarantee the right of everyone, without distinction as to race, color, or national or ethnic origin, to equality before the law, ..."

Based on the CERD, there are five prohibition criteria against racial discrimination. They are race, color, descent, national, or ethnic origin.

\section{International Covenant on Civil and Political Rights}

The ICCPR consists of 53 articles adopted and opened for signature, ratification, and accession by the General Assembly resolution 2200A (XXI) dated December 16, 1966, and valid since March 23, 1976. As a covenant in the field of civil and political rights, the ICCPR specifically regulates both civil and political rights. State parties have much better laws against racial discrimination than they have in $1970 .{ }^{43}$

The articles that emphasize the prohibition on discrimination are Articles 2, 4, 20, 24, and 26. In the articles, the term "without distinction" is also used. The articles also mention the basis or criteria for discrimination, namely race, color, sex, language, religion, political or other opinions, national or social origin, property, birth or another status.

Article 2

"(1) Each State Party to the present Covenant undertakes to respect and to ensure to all individuals within its territory and subject to its jurisdiction the rights recognized in the present Covenant, without distinction of any kind, such as race, color, sex, language, religion, political or other opinion, national or social origin, property, birth or other status.

(2) ..."

Article 4

"(1) In time of public emergency which threatens the life of the nation and the existence of which is officially proclaimed, the States 
Parties to the present Covenant may take measures derogating from their obligations under the present Covenant to the extent strictly required by the exigencies of the situation, provided that such measures are not inconsistent with their other obligations under international law and do not involve discrimination solely on the ground of race, color, sex, language, religion or social origin. (2) ..."

Article 20

"(1) ...

(2) Any advocacy of national, racial or religious hatred that constitutes incitement to discrimination, hostility or violence shall be prohibited by law."

Article 24

"(1) Every child shall have, without any discrimination as to race, colour, sex, language, religion, national or social origin, property or birth, the right to such measures of protection as are required by his status as a minor, on the part of his family, society and the State.

(2) ..."

Article 26

"All persons are equal before the law and are entitled without any discrimination to the equal protection of the law. In this respect, the law shall prohibit any discrimination and guarantee to all persons equal and effective protection against discrimination on any ground such as race, color, sex, language, religion, political or other opinion, national or social origin, property, birth or other status."

Based on the Covenant, indicators or criteria of discrimination are race, color, sex, language, religion, political or another opinion, national or social origin, property, birth, or another status. The criteria are only example and incomplete because they emphasize the word "such as". The rest criteria as another status have not included in the Covenant. However, the term another status does not explain further in the Covenant.

\section{International Covenant on Economic, Social and Cultural Rights}

The ICESCR is adopted and opened for signature, ratification and accession based on the General Assembly resolution 2200A (XXI) dated December 16, 1966, and valid since January 3, 1976. The Preamble states as follows.

"- Recognizing that, in accordance with the Universal Declaration of Human Rights, the ideal of free human beings enjoying freedom from fear and want can only be achieved if conditions are created 
whereby everyone may enjoy his economic, social and cultural rights, as well as his civil and political rights,

- Considering the obligation of States under the Charter of the United Nations to promote universal respect for, and observance of, human rights and freedoms,

- Realizing that the individual, having duties to other individuals and to the community to which he belongs, is under a responsibility to strive for the promotion and observance of the rights recognized in the present Covenant."

This Covenant contains economic, social, and cultural rights. However, several articles also contain a prohibition on discrimination, for example Article 2 (2) which states:

"The States Parties to the present Covenant undertake to guarantee that the rights enunciated in the present Covenant will be exercised without discrimination of any kind as to race, color, sex, language, religion, political or other opinion, national or social origin, property, birth or other status."

According to the Article 2 paragraph 2, the ICESCR also sets thirteen limits of discrimination criteria, namely race, color, sex, language, religion, politics or other opinions, national or social origin, wealth, birth or another status. However, the Covenant does not clearly explain the term 'another status'.

Based on the instruments containing discriminatory criteria, there are similarities and differences in terms of both number and formulation. The foundation and number of discrimination criteria are figured in following table.

Table 1. Criteria of Discrimination in the International Instruments

\begin{tabular}{|l|l|l|l|l|l|}
\hline No. & \multicolumn{1}{|c|}{$\begin{array}{c}\text { UN } \\
\text { Charter }\end{array}$} & \multicolumn{1}{|c|}{ UDHR } & \multicolumn{1}{|c|}{ ICERD } & \multicolumn{1}{|c|}{ ICESCR } \\
\hline 1. & Race & Race & Race & Race & Race \\
\hline 2. & Sex & Color & Color & Color & Colour \\
\hline 3. & Language & Sex & Descent & Sex & Sex \\
\hline 4. & Religion & Language & $\begin{array}{l}\text { National } \\
\text { origin }\end{array}$ & Language & Language \\
\hline 5. & & Religion & Ethnic origin & Religion, & Religion \\
\hline 6. & & $\begin{array}{l}\text { Political } \\
\text { opinion }\end{array}$ & $\begin{array}{l}\text { Political } \\
\text { opinion }\end{array}$ & $\begin{array}{l}\text { Political } \\
\text { opinion }\end{array}$ \\
\hline 7. & & Other opinion & & Other opinion & Other opinion \\
\hline 8. & & National origin & & National origin & National origin \\
\hline 9. & & Social origin & & Social origin & Social origin \\
\hline
\end{tabular}




\begin{tabular}{|l|l|l|l|l|l|}
\hline 10. & & Property & & property & property \\
\hline 11. & & Birth & & birth & birth \\
\hline 12. & & another status & & another status & other status \\
\hline
\end{tabular}

Based on the table, these international instruments provide differences and similarities of the criteria of discrimination. The UN Charter mentions only four criteria. The CERD has five criteria. The UDHR, the ICCPR, and the ICESCR contain thirteen each, the same. The table also shows that race is a measure of discrimination from all of these international instruments. Therefore, the United States may no longer conduct racial discrimination because it would violate these international instruments. The Floyd's and other cases indirectly provide clear evidence that the United States is still not fully implementing the international instruments. In fact, they have a responsibility to protect all citizens, despite of their skin colors.

\section{The Effects of Discrimination Towards Human Rights Protection}

The George Floyd's incident in the United States is surely a reminder of the danger of discrimination for the rest of the world. States with diverse ethnic, religious, racial, cultural, social, economic backgrounds, etc. are very vulnerable to discrimination of certain groups, mostly majority against minorities. Therefore, all parties need to be aware of the danger of discrimination to protect human rights.

The human rights protection can be disrupted if the society ignores discrimination criteria regulated in various instruments. Therefore, all people must avoid any forms of action prohibited by the instruments. If the criteria were ignored, it would violate human rights.

Discrimination in the past show ignorance and viewing differences as reason to categorize other parties improperly - for example, different treatment based on race, color, sex, and so on. The international instruments of the modern era have banned and regulated such discriminations then. Based on past negative events, the United Nations and their organs have issued the international instruments containing a prohibition on discrimination.

The practice of racial discrimination particularly brings very negative effects on the human rights protection. Groups of citizens can be treated differently due to different skin colors. Such treatment is certainly very unfair since they are also parts of the same state. In other words, racial discrimination may place certain groups of citizens as second-class citizens.

Discrimination does not only harm certain parties. It also endangers and threatens human rights in general. It threatens human existence and humanity both directly and indirectly. Instead of being treated equally, humans may be viewed as objects like goods or animals. As a result, discrimination injures humans' feelings. 
Such bad experience happened, for example, with the implementation of different laws in the United States, like the one in Mississippi. In the past, there were four kinds of law in Mississippi: plantation law, lynch law, and Negro law. The logic of "Negro law" was simple: blacks should not be held to white standards of justice for reasons beyond their biological control. To judge one race like the other was pointless; to punish both equally was unfair. The Negro had to be treated like a Negro-with patience and discipline, with flexibility and intuition, which the white Southerner did best. ${ }^{44}$

In addition, the Negro law placed the clear majority of Mississippians beyond the protection of formal statutes and written guarantees. It allowed whites to exploit blacks without legal limit, for instances to withhold the most basic rights and safeguards while claiming to be indulgent, paternalistic, and fair. It turned the criminal justice system into a corrupt and capricious entity, utterly undeserving of respect. ${ }^{45}$ This situation is certainly not expected in the modern era because it threatens certain groups and marginalizes their rights.

The danger of discrimination against human dignity is not felt personally but it threats all humanity. Differences are natural trait, but discrimination is certainly dangerous. People should treat other people with dignity instead of treating arbitrarily or hatred because of different races, ethnicities, religions, etc. Unfortunately, the fact still has not been eliminated and erased yet from modern human civilization.

The danger still exists in the United States. Indeed, the Voting Right Act 1964 has ended Jim Crow formally. However, there is a New Jim Crow. In this regard, Glaude mentions the following. ${ }^{46}$

"It may be helpful, in attempting to understand the basic nature of the new caste system, to think of the criminal justice system - the entire collection of institutions and practices that comprise it-to as an independent system but rather as a gateway into a much larger system of racial stigmatization and permanent marginalization. This larger system, referred to here as mass incarceration, is a system that locks people not only behind actual bars in actual prisons, but also behind virtual bars and virtual walls-walls that are invisible to the naked eye but function nearly as effectively as Jim Crow laws once did at locking people of color into a permanent second-class citizenship."

In the next part, Glaude emphasizes the following. ${ }^{47}$

"The term mass incarceration refers not only to the criminal justice system but also to the larger web of laws, rules, policies, and customs

44 David M. Oshinsky, Worse Than Slavery Parchman Farm and the Ordeal of Jim Crow Justice, New York: Free Press Paperback, 1997, p. 95.

45 David M. Oshinsky, op cit., pp. 95-96.

46 Eddie S. Glaude Jr, op cit., p. 10.

47 lbid. 
that control those labeled criminals both in and out of prison. Once released, former prisoners enter a hidden underworld of legalized discrimination and permanent social exclusion. They are members of America's new under caste. ${ }^{148}$

Based on the explanation above, it is not surprising that African American citizens often get an unfair treatment by their counterpart Caucasians. Some incidents of African American citizens involving Caucasian police officers indicate that it still exists. The elimination of racial discrimination in the United States is a homework for all citizens. The facts show that some people still practice racial discrimination.

In the last five years, the United States has frequently experienced discrimination incidents. Mostly, the incidents involve the Caucasians and the African American to consider them racial discrimination of the modern era. Trivial matters that can be avoided if they have no discriminatory feelings or hatred towards other groups caused most of police arrests.

BBC reports that Eric Garner's incident happened after he was wrestled to the ground by a New York police officer on suspicion of illegally selling cigarettes on July $17,2014 .{ }^{49}$ In a chokehold, Mr. Garner uttered the words "I can't breathe" eleven times. A bystander filmed the incident. The incident had triggered protests across the State. The police officer was later fired but was never prosecuted. ${ }^{50}$ Compared to the Floyd's incident, it was not far from cigarette. The Floyd's incident happened due to buying cigarettes, while the Garner's incident due to selling cigarettes. Both of them were arrested using chokehold techniques lead to breathe problems that costed their lives.

The New York Times reports the event with the title Man's Death After Chokehold Raises Old Issue for the Police. ${ }^{51}$ The news explains that the 350-pound man was about to be arrested on charges of illegally selling cigarettes. He then argued the police. When an officer tried to handcuff him, the man pulled free. The officer immediately put his arm around the man's neck, pulled him to the ground, and hold him, in what appears in a video, to be a chokehold. The man said "I can't breathe" over and over again as other officers' flock around. ${ }^{52}$

In the same year, a police officer, in Ferguson, Missouri, killed Michael Brown, eighteen years old. The officers responded to a report that Brown, who was not armed, had stolen a box of cigars. ${ }^{53}$ Still in 2014, Tamir Rice, twelve years old, was

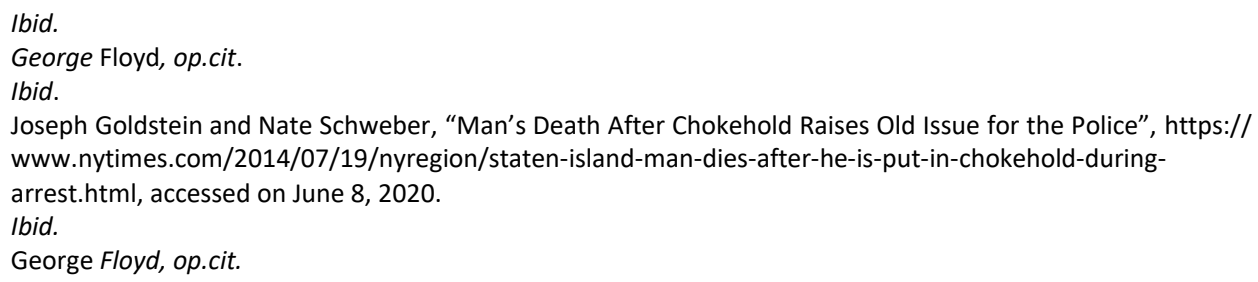


shot dead in Cleveland, Ohio by a police officer after being reported pointing a gun that was "probably fake". Police claimed that they told Rice to drop the weapon but instead of dropping it he pointed it at the officer. The police confirmed that the gun was a toy after Rice had been shot dead. ${ }^{54}$

In 2015, A Caucasian police officer shot Walter Scott, an African American, five times from behind on April 4, 2015. Mr. Scott had been pulled over for his car's defect light in North Charleston, South Carolina. He ran away from the officer. The killing sparks protests in North Charleston, chanting "No justice, no peace". ${ }^{55}$ The same, the case of Alton Sterling's death lead to days of protests in Baton Rouge, Louisiana. Mr. Sterling was killed after police responded a report of a disturbance outside a shop. The incident was caught on mobile phone footage and gone viral online. $^{56}$

Due to various police disproportionately and unprofessionally actions, in 2016, the International Association of Chiefs of Police (largest police management organization) issued a formal apology to the minority population "for the actions of the past and the role that our profession has played in society's historical mistreatment of communities of color". They recognized the role that the police played as enforcers of racist and discriminatory policies. ${ }^{57}$

However, this does not immediately stop the actions of racist police in handling crime. Events of discrimination continue to occur in 2016, 2018, and even a few months before the Floyd's case in 2020. Philando Castile was killed while driving out with his girlfriend in St. Paul, Minnesota on July 6, 2016. Philando Castile was pulled over by the police during a routine check. Castille told the officer that he was licensed to carry a weapon and had one in his possession. He was shot as he reached for his license, according to his girlfriend. She streamed the encounter on Facebook. ${ }^{58}$

In 2018, Stephon Clark died after being shot at least seven times in Sacramento, California, by police who were investigating a break-in. The district attorney said that the police had not committed a crime, as the officers said they feared for their lives believing Mr. Clark was armed. Only a mobile phone was found at the scene. The release of a police video of the incident sparked major protests in the city. Nevertheless, the incident did not result in a wave of overly massive protests like the Floyd's case.

In 2018, Breonna Taylor, a 26-year-old emergency medical technician, was shot eight times after officers raided her apartment in Lousville, Kentucky. The police were executing a search warrant as part of a drugs raid, but no drugs were found. The Louisville police officer says they returned fire after one officer was shot

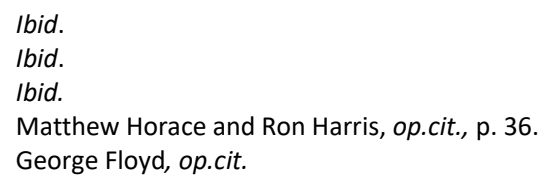


and wounded in the incident. The family has filed a lawsuit for wrongful death and excessive force. It says that Ms. Taylor's partner fired in self-defense because the police did not identify themselves, and he believed they were being burgled. ${ }^{59}$

The examples show that one of the causes of discrimination is inequality among citizens. The law still discriminates by treating certain citizens differently from other. In other words, discriminatory treatment occurs because there is no recognition and application of the principle of equality to citizens. Unsurprisingly, racial discrimination brings the whites to dominate in social life in the United States. There are at least 15-major professions that are dominated by them, as shown in following table. ${ }^{60}$

Table 2. Fifteen Major Professions in the US

\begin{tabular}{|r|l|l|}
\hline No. & \multicolumn{1}{|c|}{ Profession } & \multicolumn{1}{|c|}{ Occupation } \\
\hline 1. & Ten richest Americans & 100 percent white \\
\hline 2. & US Congress & 90 percent white \\
\hline 3. & US governors & 96 percent white \\
\hline 4. & Top military advisers & 100 percent white \\
\hline 5. & President and vice president & 100 percent white \\
\hline 6. & US House Freedom Caucus & 99 percent white \\
\hline 7. & Current US presidential cabinet & 91 percent white \\
\hline 8. & People who decide which TV shows we see & 93 percent white \\
\hline 9. & People who decide which books we read & 90 percent white \\
\hline 10. & People who decide which news is covered & 85 percent white \\
\hline 11. & People who decide which music is produced & 95 percent white \\
\hline 12. & People who directed the one hundred top-grossing & 95 percent white \\
\hline 13. & films of all time, worldwide & 82 percent white \\
\hline 14. & Full-time college professors & 84 percent white \\
\hline 15. & Owners of men's professional football teams & 97 percent white \\
\hline
\end{tabular}

Based on the table, it appears that the whites occupy all-important professions in the United States, above 80 percent on average compared to other ethnics. Ten richest Americans, top military advisers, presidents, and vice presidents are 100 percent whites. By coincidence, the fact shows that racial discrimination still exists and leaves the black community far behind in almost everything. The table also shows that the lives of citizens are not yet fully free from racial discrimination that affects employment. Indeed, law and various international human rights instruments already prohibit racial discrimination in various forms. However, this 
has not been fully realized. Therefore, the United States has the duty and responsibility to eliminate all forms of racial discrimination.

\section{E. Conclusion}

The recurring racial discrimination issue in the modern era indicates that the fight against racial discrimination in the United States has not been entirely successful. The Floyd's case, as well as other cases, is only the tip of iceberg of discriminatory practices. This state of affairs certainly affects human rights protection and enforcement. As a developed state, the United States has apparently not been able to realize state's responsibilities to protect the human rights of their citizens.

In the context of human rights, all people are equal before the law and must be treated fairly and humanely. The impact of racial discrimination can be very dangerous to the human rights existence and protection. Numerous racial incidents in the United States happened recently show that the belief of certain group superior heritage against another group still exists. Therefore, all groups must eradicate such superiority culture to strike out racial discrimination.

The fight against racial discrimination in the United States seems to be an endless struggle. Therefore, the government should consistently carry out their national laws. In addition, they must also pay attention to and carry out all international instruments of human rights. This is important to prevent the recurrence of more racial discrimination cases, like the Floyd's case, in the forthcoming.

\section{References}

\section{Books}

Addison, Kenneth N, "We Hold These Truths to Be Self-Evident ..." An Interdisciplinary Analysis of the Roots of Racism and Slavery in America, University Press of America, Maryland, 2009.

Appelt, Erna, and Monika Jarosch (eds), Combating Racial Discrimination Affirmative Action as a Model for Europe, Berg, New York, 2000.

Banton, Michael, International Action against Racial Discrimination, Clarendon Press, Boston, 2003.

Chemerinsky, Erwin, Constitutional Law Principles and Policies, Aspen Publishers, Inc., New York, 2002.

Churchwell, Sarah, Behold America a History of America First and the American Dream, $1^{\text {st }}$ edition, Bloomsbury Publishing, London, 2018.

Diangelo, Robin, White Fragility Why It's So Hard for White People to Talk Racism, Beacon Press, Boston, 2018.

Fleming, Crystal M, How to Be Less Stupid About Race on Racism, White Supremacy, and the Racial Divide, Beacon Press, Boston, 2018.

Flexon, Jaemi L., Racial Disparities in Capital Sentencing Prejudice and Discrimination in the Jury, LFB Scholarly Publishing LLC, EI Paso, 2012. 
Friedman, Lawrence M., and Grant M. Hayden, American Law an Introduction, Oxford University Press, England, 2017.

Garner, Bryan A, (ed.), Black's Law Dictionary, West a Thomson Reuters Business, New York, 2009.

Glaude, Eddie S. Jr, Democracy in Black How Race Still Enslave the American Soul, Crown Publisher, New York, 2016.

Hernadi Affandi, Persamaan Kedudukan di Depan Hukum dan Pemerintahan Konsepsi dan Implementasi, CV. Mujahid Press, Bandung, 2017.

Horace, Matthew, and Ron Harris, The Black and The Blue a Cop Reveals the Crimes, Racism, and Injustice, in America's Law Enforcement, Hachette Book Group, New York, 2018.

Jillson, Cal, American Government Constitutional Democracy Under Pressure, Routledge, New York, 2018.

Lehman, Paul R, America's Race Problems a Practical Guide to Understanding Race in America, University Press of America, Maryland, 2009.

Martin, Elizabeth A., and Jonatan Law (eds), Oxford a Dictionary of Law, Oxford University Press, Oxford, 2006.

Nowak, Manfred, Introduction to the International Human Rights Regime, Martinus Nijhoff Publishers, Leiden, 2003.

Oshinsky, David M, Worse Than Slavery Parchman Farm and the Ordeal of Jim Crow Justice, Free Press Paperback, New York, 1997.

Patterson, Thomas E, The American Democracy, $2^{\text {nd }}$ edition, McGraw-Hill, Inc, New York, 1993.

----------, We the People an Introduction to American Government, $11^{\text {th }}$ edition, McGraw-Hill Education, New York, 2013.

Risjord, Norman K, America, A History of the United States, Volume 1 to 1877, Prentice-Hall, Inc, New Jersey, 1985.

Smith, Mark S., How is Race Made, Slavery, Segregation, and the Senses, The University of South Carolina Press, Chapel Hill, 2006.

Weissberg, Robert, Understanding American Government, Random House School Division, New York, 1988.

\section{Other Documents}

BBC News, "George Floyd: What happened in the final moments of his life", https://www.bbc.com/news/ world-us-canada-52861726, accessed on June 7, 2020.

--------, "George Floyd: Timeline of black deaths caused by police", https://www.bbc.com/news/world-us-canada-52905408, accessed on June 7, 2020.

Eidi, Asbjorn, "Economic, Social, and Cultural Rights as Human Rights" in Asbjorn Eidi, (et.all), Economic, Social, and Cultural Rights a Textbook, $2^{\text {nd }}$ revised 
edition, Kluwer Law International dan Martinus Nijhoff Publisher, Dodrecht, 2011.

Hemond, Elaine, "Women's Poltical Equality the Project of the Century", Groupe Femmes et Democratie Papers, Vol. 7, No. 2, December 2007.

Joseph Goldstein and Nate Schweber, "Man's Death After Chokehold Raises Old Issue for the Police", https://www.nytimes.com/2014/07/19/nyregion/statenisland-man-dies-after-he-is-put-in-chokehold-during-arrest.html, accessed on June 8,2020

Widdershoven, Rob, "European Administrative Law", in Administrative Law of the European Union, its Member States and the United States: A Comparative Analysis, Rene Seerden and Frits Stroink (eds), Intersentia Uitgevers Antwerpen, Groningen, 2002.

United Nation, Inter-Parliamentary Union, The Convention on the Elimination of All Forms of Discrimination against Women and its Protocol, Handbook for Parliamentarians, Secretary of the Publication Boards, United Nations Headquarters, New York, NY 10017, USA, 2003.

\section{Legal Documents}

Charter of the United Nations (United Nations Charter).

Universal Declaration of Human Rights (UDHR).

International Covenant on Civil and Political Rights (ICCPR).

International Covenant on Economic, Social, and Cultural Rights (ICESCR)

International Convention on the Elimination of All Forms of Racial Discrimination (CERD). 